\title{
Peningkatan Kemampuan Penalaran Matematika dan Sikap Siswa melalui Penerapan Pembelajaran Matematika dengan Pendekatan Open Ended pada Siswa Kelas VIII-2 SMPN 7 Padangsidimpuan
}

\author{
Yuni Rhamayanti, Nurdalilah \\ Jurusan Pendidikan Matematika, Universitas Graha Nusantara (UGN) Padangsidimpuan. Kampus II \\ Simarsayang, Padangsidimpuan, Medan, Indonesia. \\ ritongayunirhamayanti@gmail.com
}

\begin{abstract}
This research was conducted on junior high school students with the aim of improving mathematical reasoning abilities, student activity and student attitudes towards the application of open ended approach learning. This type of research is Classroom Action Research. The subject of this study is the eighth grade students of SMP Negeri 7 Padangsidimpuan 2017-2018 Academic Year, which are selected in class VIII-2 with a total of 24 students. The conclusions that can be drawn from this study are 1) increasing mathematical reasoning abilities through the application of mathematical learning with an open-ended approach to students of class VIII-2. The increase in students' mathematical reasoning abilities was obtained at 0.5 with the medium criteria, 2) increasing student learning activities through the application of mathematics learning with an open-ended approach to students of class VIII2. The increase in student activity was obtained at 0.46 with moderate criteria, 3) increasing student attitudes towards mathematics through the application of mathematics learning with an open-ended approach to students of class VIII-2. The increase in student activity is 0.6 with moderate criteria.
\end{abstract}

Keywords: Mathematical reasoning Ability, Activity, Attitude, Open ended

(c) Th This is an open access article distributed under the Creative Commons 4.0 Attribution License, which permits unrestricted use, distribution, and reproduction in

\section{PENDAHULUAN}

Matematika sangat dibutuhkan dalam menghadapi situasi dan kondisi perkembangan teknologi dan informasi masa depan. Kemampu an untuk menghadapi permasalahan-permasalah an baik dalam permasalahan matematika maupun permasalahan dalam kehidupan nyata merupakan daya matematis (mathematical power). Untuk dapat menumbuh kembangkan daya matematis siswa dalam pelaksanaan pembelajaran, maka kegiatan pembelajaran harus membawa siswa dalam menjawab permasalahan dengan banyak cara dan mungkin juga banyak jawaban (yang benar). Dengan demikian akan menggugah kemampuan penalaran siswa dan mampu me ningkatkan potensi intelektual serta pengalaman siswa dalam proses menemukan sesuatu yang baru (Sumarmo, 2013).

Pengembangan penalaran berarti juga pengembangan berpikir dasar, berpikir kritis, dan berpikir kreatif, tetapi tidak termasuk mengingat (recall). Sejalan dengan itu, istilah penalaran (reasoning) dijelaskan Keraf (1982:5) sebagai: "Proses berpikir yang berusaha menghubunghubungkan fakta-fakta atau kejadian-kejadian yang diketahui menuju kepada suatu kesim pulan". Pada intinya, penalaran merupakan suatu proses atau suatu aktivitas berpikir untuk menarik kesimpulan atau membuat suatu per nyataan baru yang benar berdasar pada beberapa pernyataan kebenaran nya telah dibuktikan atau diasumsikan sebelumnya. Kemampuan penalar an siswa merupakan aspek penting, karena dapat digunakan untuk menyelesaikan masalah-masalah lain, baik masalah matematika maupun masalah kehidupan sehari-hari. Depdiknas (2012 :6) menyatakan bahwa "Materi matematika dan penalaran matematika merupakan dua hal yang tidak dapat dipisahkan, yaitu materi matematika dipahami melalui penalaran dan penalaran dipahami dan dilatihkan melalui belajar materi matematika." Pola berpikir yang dikembangkan matematika memang membutuhkan dan melibat kan pemikiran kritis, sistematis, logis dan kreatif". Betapa pentingnya aspek penalaran ini, maka perlu adanya pengembang an kemampuan penalaran siswa dalam pem belajaran matematika.

Namun berdasarkan kenyataan, proses pembelajaran matematika saat ini masih di dominasi oleh metode konvensional dengan menjelaskan apa-apa yang telah dipersiapkan nya 
dan siswa menjadi penerima informasi yang baik. Dalam proses pembelajaran guru umumnya melakukan penilaian masalah hanya pada hasil akhirnya saja, yang merupakan tujuan utama dalam pembelajaran dan jarang memperhatikan proses penyelesaian masalah menuju ke hasil akhir. Kebanyakan siswa hanya diajarkan untuk mengingat rumus dan meng gunakannya dalam urutan langkah-langkah yang harus diikuti. Setelah siswa belajar matematika biasanya di lanjutkan mengerjakan soal. Proses pembelajaran yang demikian meng akibatkan siswa hanya mencontoh apa yang dikerjakan guru (Armanto, 2009). Untuk menyelesaikan soal, siswa berupaya mengikuti langkah-langkah yang telah diajarkan oleh guru. Berarti nalar siswa dalam mengerjakan soal tidak jalan karena hanya mengikuti apa yang telah diajarkan. Kalaupun siswa bernalar, siswa tidak bisa melepaskan diri dari langkah-langkah yang diberikan oleh guru. Akibat yang paling sering siswa rasakan, kalau mengalami ke buntuan mengerjakan soal maka biasanya kebanyakan dari siswa menyerah karena tidak tahu apa yang harus dilaku kan. Padahal proses penyelesaian suatu masalah menuju ke hasil akhir merupakan salah satu daya pikir (penalaran) yang interaktif antara siswa dan matematika, hal ini nantinya akan berdampak pada siswa dalam menyelesaikan suatu masalah dengan berbagai macam strategi penyelesaian.

Namun, guru juga masih beranggapan bahwa dengan memberikan tugas yang banyak akan membuat siswa lebih terlatih dan meningkat kan hasil belajarnya. Padahal pem berian tugas kepada siswa yang cukup banyak tanpa mem perdulikan kualitas dan bentuk tugas akan membuat siswa semakin menjauhi dan mem benci pelajaran matematika. Kurang ter bukanya siswa dalam komunikasi dengan guru untuk membicarakan materi matematika di kelas, hal ini disebabkan siswa masih merasa takut dan belum terbiasa dengan suasana pembelajaran matematika yang memberikan keleluasaan siswa dalam memberikan ide atau gagasan. Hal ini menyebabkan siswa kurang memiliki kemampu an menyelesaikan masalah dengan alternatif lain. Padahal proses berpikir untuk mendapatkan pe nyelesaian masalah lebih dari satu alternatif merupakan salah satu kemampuan penalaran yang harus dikembang kan pada siswa.

Salah satu permasalahan misalnya siswa diberikan pertanyaan berapa 6 kali 2, pastilah siswa akan menjawab tanpa berpikir panjang adalah 12. Tapi bila diberikan pertanyaan bagai mana mendapatkan nilai 12 ? Tentulah para siswa akan berpikir tentang angka-angka yang bila dioperasikan menghasilkan nilai 12 . Siswa mung kin akan meresponnya yang salah satunya seperti $2+2+2+2+2+2,4+4+4,6+6,6 \times 2$ dan lain sebagainya. Kesemuanya itu adalah benar pada alasan masing-masing siswa. Hal seperti inilah yang dapat menggugah siswa untuk bernalar pada suatu masalah dan siswa akan berani mengemukakan ide-idenya karena per tanyaan tersebut adalah terbuka, selain itu dengan sendirinya siswa akan saling menghargai keragaman ide-ide yang muncul dalam men jawab pertanyaan. Jadi proses pembelajaran seperti ini merupakan hasil dari refleksi pembelajaran yang mengedepankan masalah terbuka.

Pembelajaran yang mengedepankan masalah terbuka dengan banyak alternatif jawab an atau banyak alternatif untuk mendapatkan jawaban sering disebut pendekatan pembelajaran open ended, yaitu pembelajaran matematika yang dapat memberikan keleluasaan siswa untuk berpikir secara aktif dan kreatif dalam rangka me ningkatkan daya nalar siswa serta mengeksplor secara terbuka hasil penalarannya dalam me mecahkan masalah tertentu dan mengkomunikasi kan hasil pemikiran tersebut dalam bentuk lisan maupun tulisan. Pernyataan ini didasari pernyata an Nohda (2001) bahwa pendekatan open ended bermanfaat untuk meningkatkan cara berpikir siswa.

Dalam Proses Belajar Mengajar melalui pendekatan open ended sangat sesuai dengan paradigma baru pendidikan, dimana dalam pembelajaran dengan pendekatan open ended dimulai dengan memberikan problem terbuka kepada siswa. Mereka diminta untuk me ngembangkan metode, cara yang berbeda-beda dalam upaya memperolah jawaban yang benar, dimana guru tetap menjadi fasilitator dan membimbing siswa. Dari hasil jawaban siswa tersebut didiskusikan adanya berbagai ke mungkinan cara menjawab dan berbagai hasil akhir yang mungkin berbeda. Penyampaian jawaban siswa ini penting guna memberikan ke percayaan kepada siswa bahwa cara mengerjakan suatu masalah maupun jawaban akhir yang benar tidak selalu sama. Kegiatan ini diharapkan pula dapat membawa siswa untuk menjawab per masalahan dengan banyak cara, sehingga me ngundang potensi intelektual dan pengalaman siswa dalam proses menemukan sesuatu yang baru. Dengan demikian maka proses pembelajar an akan mengembangkan penalaran siswa dalam 
memecahkan masalah sehingga dapat meningkat kan ketuntasan belajar dan sikap positif siswa terhadap matematika.

Berdasarkan uraian permasalahan di atas, peneliti tertarik untuk mengadakan penelitian untuk melihat peningkatan kemampuan penalar an matematika dan sikap siswa melalui penerap an pembelajaran matematika dengan pendekatan open ended pada siswa kelas VIII-2 SMP Negeri 3 Padangsidimpuan Tahun Pelajaran 2017-2018.

Berdasarkan uraian di atas, maka rumusan masalah dalam penelitian ini adalah 1) Bagai mana peningkatan kemampuan penalaran mate matika melalui penerapan pembelajaran mate matika dengan pendekatan open ended pada siswa kelas VIII-2?, 2) Bagaimana peningkatan aktivitas belajar siswa melalui penerapan pem belajaran matematika dengan pendekatan open ended pada siswa kelas VIII-2?, dan 3) Bagaimana peningkatan sikap siswa terhadap matematika melalui penerapan pembelajaran matematika dengan pendekatan open ended pada siswa kelas VIII-2?

Adapun tujuan dari penelitian ini a.dalah 1) Untuk meningkatkan kemampuan penalaran matematika melalui penerapan pembelajaran matematika dengan pendekatan open ended pada siswa kelas VIII-2, 2) Untuk meningkatkan aktivitas belajar siswa melalui penerapan pembelajaran matematika dengan pendekatan open ended pada siswa kelas VIII-2, 3) Untuk meningkatkan sikap siswa terhadap matematika melalui penerapan pembelajaran matematika dengan pendekatan open ended pada siswa kelas VIII-2.

\section{METODE PENELITIAN}

Jenis penelitian ini adalah penelitian tindakan kelas (Classroom Action Research). PTK berfokus pada kelas atau proses belajarmengajar yang terjadi di kelas. (Arikunto, 2012,). Desain penelitian tindakan kelas untuk setiap siklusnya meliputi: 1) permasalahan, 2) pe rencanaan tindakan, 3) pelaksanaan tindakan, 4) observasi, 5) analisis data, dan 6) refleksi (Suharsimi Arikunto, 2012). Pada penelitian ini jika siklus I hasil belajar matematika dan aktivitas siswa belum mencapai ketuntasan, maka dilaksanakan siklus II yang tahapan kegiatannya sama dengan tahapan siklus I. Akan tetapi pada siklus II akan dilakukan beberapa tambahan perbaikan dari tindakan sebelumnya yang ditujukan untuk memperbaiki berbagai hambatan atau kesulitan yang ditemukan pada siklus I.

Subjek penelitian ini adalah siswa kelas VIII SMP Negeri 7 Padangsidimpuan pada semester genap tahun pelajaran 2017-2018, yang dipilih adalah kelas VIII-2 dengan jumlah siswa 24 orang. Adapun alasan peneliti memilih kelas ini adalah berdasarkan hasil tes awal yang dilakukan bahwa kelas tersebut memiliki hasil belajar yang masih rendah sehingga masih perlu untuk ditingkatkan. Sedangkan objek penelitian ini adalah penerapan pembelajaran matematika dengan pendekatan open ended untuk peningkat an kemampuan penalaran matematika, aktivitas belajar siswa dan sikap siswa terhadap mate matika yang kurang baik dan perlu diperbaiki.

Untuk keperluan pengumpulan data, maka dalam hal ini perlu instrumen penelitian. Instrumen penelitian pada penelitian ini akan menggunakan teknik tes dan non tes. "Tes merupakan salah satu alat untuk mengukur terjadinya perubahan tingkah laku pada siswa setelah berlangsung serangkaian proses belajar mengajar" (Trianto, 2011). Adapun tes yang digunakan adalah kemampuan penalaran mate matika siswa berupa soal-soal berbentuk uraian. Sebelum tes digunakan dalam penelitian terlebih dahulu meminta pertimbangan pakar untuk pengembangan dan dilakukan uji coba instrumen untuk mengetahui validitas, realibilitas, daya beda dan tingkat kesukaran tes. Menghitung Validitas dan Realibilitas dengan secara manual, excel dan dengan menggunakan SPSS.

Sedangkan Non tes adalah lembar observasi dan skala sikap. Menurut ahli bahwa: "salah satu kegiatan penting dalam proses pembelajaran adalah pengamatan (observasi)" (Trianto, 2011). Observasi terhadap siswa dilaku kan oleh peneliti untuk melihat keaktifan siswa dalan mengikuti pelajaran. Sedangkan Peng gunaan skala sikap bertujuan untuk mengetahui bagaimana sikap siswa terhadap pembelajaran matematika dengan pendekatan open ended, serta untuk mengetahui sikap siswa terhadap soal- soal yang mengukur kemampuan penalaran mate matika siswa.

\section{Analisis Data Tes Kemampuan Penalaran Matematika}

Setiap lembar jawaban siswa dikoreksi untuk mengetahui tingkat kemampuan penalaran matematika siswa. Penentuan skor untuk hasil kerja siswa dilakukan dengan memberikan penilaian. Adapun langkah yang ditempuh adalah 


$$
\text { Nilai }=\frac{\text { Skor mentah }}{\text { Skor maks Ideal (SMI) }} \times 100
$$

Ket $:$ SMI $=$ Jumlah soal essay $x$ bobot nilai $=$ jumlah skor

Selanjutnya tingkat penguasaan tersebut akan tercermin pada tinggi rendahnya nilai yang dicapai. Pedoman konversi yang digunakan adalah sebagai berikut :

Tabel 1. Pedoman Konversi Nilai

\begin{tabular}{c|c}
\hline Skor Nilai & Kategori \\
\hline $90-100$ & Sangat Baik \\
\hline $80-89$ & Baik \\
\hline $65-79$ & Cukup Baik \\
\hline $55-64$ & Kurang \\
\hline $0-54$ & Sangat Kurang \\
\hline
\end{tabular}

Nurkancana (1986:80)

\section{Analisis Hasil Observasi Aktivitas Siswa}

Pelaksanaan observasi ini dilakukan pada saat pembelajaran berlangsung dimana peneliti meminta bantuan dari guru matematika sebagai observer untuk mengamati apakah kondisi belajar mengajar sudah terlaksana sesuai dengan skenario pembelajaran. Analisis data pengelolaan observasi ini diperoleh dari kegiatan pembelajara an dengan pendekatan open ended dengan ketentuan sebagai berikut:

$$
\begin{aligned}
& 1=\text { kurang } \\
& 2=\text { cukup } \\
& 3=\text { baik } \\
& 4=\text { sangat baik }
\end{aligned}
$$

Dari hasil observasi yang telah dilakukan observer siswa dilakukan penganalisasan dengan menggunakan rumus:

$$
\% \text { aktivitas }=\frac{\text { Frekuensi }}{\text { Jumlah frekuensi }} \times 100 \%
$$

Adapun kriteria penilaian observasi yaitu:

Tabel 2. Kategori Penilaian Observasi

\begin{tabular}{c|c}
\hline Skor Nilai & Kategori \\
\hline $90 \%-100 \%$ & Baik Sekali \\
\hline $80 \%-89 \%$ & Baik \\
\hline $65 \%-79 \%$ & Cukup \\
\hline $55 \%-64 \%$ & Kurang \\
\hline$\leq 54 \%$ & Sangat Kurang \\
\hline
\end{tabular}

Nurkancana (1986:80)

Sedangkan untuk menghitung peningkatan kemampuan penalaran matematika, aktivitas belajar dan sikap siswa terhadap matematika melalui Pembelajaran dengan pendekatan open ended menggunakan rumus gain yaitu :

$$
(g)=\frac{\text { Nilai Postes - Nilai Pretes }}{\text { Nilai Ideal - Nilai Pretes }}
$$

Kriteria indeks gain adalah:

$$
\begin{array}{ll}
g>0,7 & \text { tinggi } \\
0,3<g \leq 0,7 & \text { sedang } \\
g \leq 0,3 & \text { rendah }
\end{array}
$$

\section{Indikator Keberhasilan}

Berdasarkan tujuan penelitian yang ingin dicapai, maka disusunlah indikator keberhasilan dalam penelitian ini sebagai berikut:

1. Peningkatan kemampuan penalaran matematika melalui penerapan pembelajaran dengan pendekatan open ended dilihat dari $80 \%$ siswa yang mengikuti tes memperoleh nilai minimal cukup.

2. Peningkatan kemampuan penalaran matematika melalui penerapan pembelajaran dengan pendekatan open ended ditandai dengan kadar aktivitas siswa mencapai nilai minimal $80 \%$.

3. Peningkatan kemampuan penalaran matematika melalui penerapan pembelajaran dengan pendekatan open ended ditandai dengan sikap siswa terhadap matematika mencapai nilai minimal $80 \%$.

\section{HASIL DAN PEMBAHASAN}

\section{Deskripsi Hasil Penelitian Tindakan Kelas (PTK)}

a. Tes Kemampuan Penalaran Matematika

Siswa Siklus I

Hasil penelitian tindakan siklus I diuraikan dalam beberapa tahapan. Adapun tahapan yang dilakukan dalam proses Penelitian Tindakan Kelas (PTK) yaitu perencanaan tindakan, pelaksanaan tindakan, observasi dan refleksi. Diakhir pembelajaran siklus I berlangsung, di laksanakan postes kemampuan penalaran mate matika siswa, maka hasil yang didapat dari tes tersebut dapat dilihat pada tabel berikut ini:

Tabel 3. Pengklasifikasian Kemampuan

Penalaran Matematika Siklus I

\begin{tabular}{c|c|c|c}
\hline No & Nilai & Jumlah & Kualifikasi \\
\hline 1 & $90-100$ & $3(12.5)$ & Sangat Baik \\
\hline 2 & $80-89$ & $5(20.8)$ & Baik \\
\hline 3 & $65-79$ & $8(33.4)$ & Cukup \\
\hline 4 & $55-64$ & $3(12.5)$ & Kurang \\
\hline 5 & $0-54$ & $5(20.8)$ & Sangat Kurang \\
\hline \multicolumn{2}{c}{ Total } & $\mathbf{2 4}$ & \\
\hline
\end{tabular}

Berdasarkan tabel 3 diatas, dari 24 siswa yang mengikuti tes kemampuan penalaran matematika diperoleh 3 orang atau $12.58 \%$ siswa 
dengan kategori "Sangat Baik", 5 orang siswa atau $20.8 \%$ dengan kategori "Baik", 8 orang siswa atau 33.4\% dengan kategori "Cukup", 4 orang siswa atau $12.5 \%$ dengan kategori "Kurang", dan 3 orang siswa atau $12.5 \%$ dengan kategori "Sangat Kurang". Namun peningkatan ini belum mencapai kriteria ketuntasan yang diharapkan, karena jumlah siswa yang mem peroleh kategori minimal cukup sebanyak 16 orang siswa atau $66.7 \%$ dari 24 siswa yang mengikuti tes, sehingga belum sesuai dengan target yang telah ditetapkan $80 \%$ maka diadakan refleksi pada siklus berikutnya yaitu siklus II.

Untuk lebih jelasnya dapat dicermati grafik yang menggambarkan tingkat kemampuan penalaran matematika siswa di siklus I sebagai berikut:

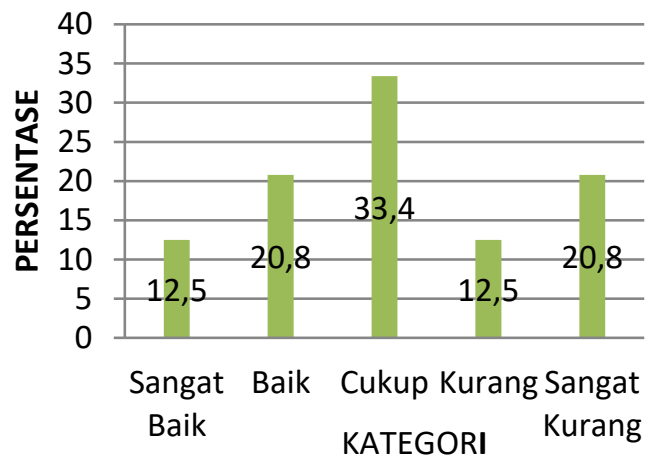

Gambar 1. Diagram Kemampuan Penalaran Matematika Siklus I

Dari tabel 3 dan diagram 1 di atas dapat diketahui bahwa kemampuan penalaran mate matika siswa berada pada kategori "cukup". Untuk itu perlu adanya perbaikan dan peningkat an pada proses pembelajaran siklus berikutnya atau pada siklus II. Diharapkan pada siklus berikutnya kemampuan penalaran matematika siswa pada kategori "sangat baik" bertambah dan kategori "sangat kurang" diharapkan mengalami penurunan.

\section{b. Hasil Observasi Aktivitas Siswa}

Pengamatan atau observasi adalah bagian dari proses pengumpulan data yang diperlukan dalam penelitian. Pengamatan dalam penelitian ini dilaksanakan ketika proses tindakan ber langsung yang dilakukan oleh observer yang memiliki peran mengamati dan memotret semua aktivitas siswa yang terjadi di kelas ketika tindakan dilakukan.

Hasil pengamatan terhadap aktivitas siswa dalam pembelajaran setiap pertemuan selama 3 kali tatap muka dinyatakan dengan persentasi.
Hasil tersebut disajikan secara ringkas pada tabel berikut:

Tabel 4 Hasil Observasi Aktivitas Siswa Siklus I

\begin{tabular}{|c|c|c|c|c|c|c|}
\hline \multirow[b]{2}{*}{ No } & \multirow[b]{2}{*}{ Indikator } & \multicolumn{3}{|c|}{ Pertemuan } & \multirow{2}{*}{$\begin{array}{l}\text { Rata- } \\
\text { rata }\end{array}$} & \multirow{2}{*}{$\begin{array}{l}\text { Perse } \\
\text { n }(\%)\end{array}$} \\
\hline & & I & II & III & & \\
\hline 1 & $\begin{array}{l}\text { Membaca dan } \\
\text { memahami soal } \\
\text { LKS }\end{array}$ & 1 & 4 & 1 & 2.0 & 50.0 \\
\hline 2 & $\begin{array}{l}\text { Sering } \\
\text { mengajukan } \\
\text { pertanyaan yang } \\
\text { baik } \\
\end{array}$ & 2 & 4 & 4 & 3.3 & 83.3 \\
\hline 3 & $\begin{array}{l}\text { Sering banyak } \\
\text { gagasan dan usul }\end{array}$ & 3 & 1 & 4 & 2.7 & 66.7 \\
\hline 4 & $\begin{array}{l}\text { Bebas dalam } \\
\text { menyatakan } \\
\text { pendapat }\end{array}$ & 3 & 3 & 3 & 3.0 & 75.0 \\
\hline 5 & $\begin{array}{l}\text { Memiliki } \\
\text { pendapat sendiri } \\
\text { dan mampu } \\
\text { mengutarakannya }\end{array}$ & 1 & 3 & 2 & 2.0 & 50.0 \\
\hline 6 & $\begin{array}{l}\text { Tidak mudah } \\
\text { terpengaruhi } \\
\text { orang lain }\end{array}$ & 2 & 3 & 3 & 2.7 & 66.7 \\
\hline 7 & $\begin{array}{l}\text { Kerja sama siswa } \\
\text { dalam kelompok }\end{array}$ & 3 & 2 & 4 & 3.0 & 75.0 \\
\hline 8 & $\begin{array}{l}\text { Perhatian } \\
\text { terhadap materi } \\
\text { pelajaran }\end{array}$ & 3 & 4 & 2 & 3.0 & 75.0 \\
\hline 9 & $\begin{array}{l}\text { Dapat bekerja } \\
\text { sendiri }\end{array}$ & 2 & 3 & 3 & 2.7 & 66.7 \\
\hline 10 & $\begin{array}{l}\text { Mampu membuat } \\
\text { kesimpulan }\end{array}$ & 3 & 4 & 2 & 3.0 & 75.0 \\
\hline & Jumlah & 23 & 31 & 28 & 27.3 & 683.3 \\
\hline & Rata-rata nilai & \multicolumn{5}{|c|}{2.73} \\
\hline & Persentase & \multicolumn{5}{|c|}{$68.3 \%$} \\
\hline & Kualifikasi Nilai & \multicolumn{5}{|c|}{ Cukup } \\
\hline
\end{tabular}

Dari tabel 4 hasil observasi aktivitas siswa

siklus I di atas dapat dijelaskan persentase klasikal siklus I adalah $68.3 \%$ sedangkan untuk kualifikasi nilai adalah Cukup. Dari hasil observasi aktivitas siswa siklus I di atas dapat dijelaskan bahwa hasil observasi aktivitas siswa belum sesuai dengan apa yang direncanakan dalam penelitian ini adalah $\geq 80 \%$. Secara keseluruhan pencapaian aktivitas siswa pada siklus I dapat dilihat pada gambar berikut ini: 


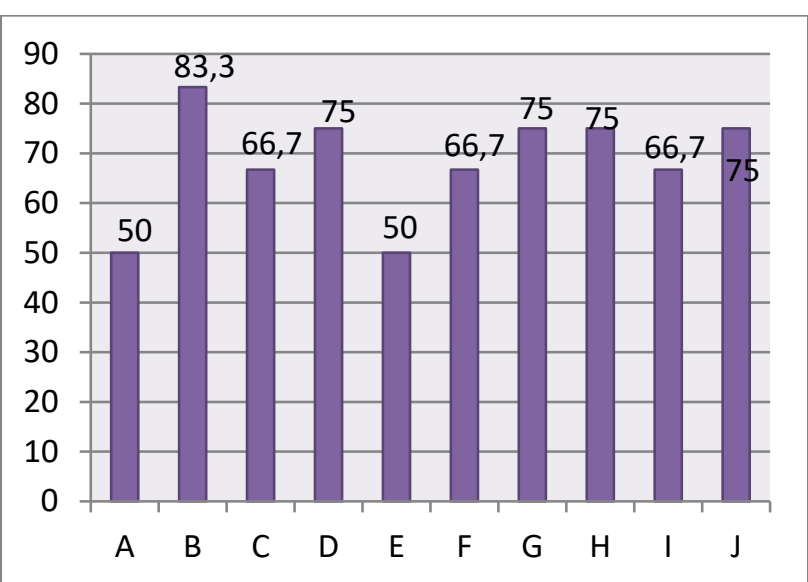

Gambar 2 Diagram Kadar Aktivitas Siswa Siklus I

Berdasarkan uraian di atas, terlihat hasil observasi aktivitas aktif siswa untuk siklus I berjalan dengan baik, namun ditinjau dari hasil non tes siswa yang belum memenuhi kriteria minimal $80 \%$ siswa berada pada kategori cukup baik dari seluruh siswa yang mengikuti tes, maka disimpulkan bahwa penelitian ini akan dilanjutkan pada siklus II.

\section{c. Hasil Sikap Siswa Terhadap Matematika}

Untuk mendapatkan data tentang jawaban responden belajar siswa melalui model pem belajaran dengan pendekatan open ended. Angket sikap siswa dalam kegiatan belajar dan terhadap perangkat pemebelajaran yang di kembangkan dan diisi oleh siswa setelah kegiatan pembelajaran selesai. Jumlah siswa yang mengisi angket sikap siswa sebanyak 24 orang dan jumlah soal angket sebanyak 10 butir. Setiap butir soal angket terdapat 5 pilihan.

Setelah melakukan penyebaran angket sikap siswa melalui pembelajaran dengan pen dekatan open ended maka persentase perolehan pada siklus I ini sebesar $57.6 \%$ dengan kualifikasi nilai cukup artinya siswa kurang setuju bahwa belajar matematika tersebut itu kurang menyenangkan dan tidak mampu mem berikan pengaruh yang sangat baik terhadap peningkatan kemampuan penalaran matematika siswa, maka perlu perbaikan pada siklus berikut nya yaitu siklus II

\section{Deskripsi Refleksi Pada Siklus I}

a. Tes Kemampuan Penalaran Matematika

Pada siklus 1 hasil refleksi yang ditemu kan oleh peneliti, siswa masih ribut dalam kelas dikarenakan masih banyak siswa yang diganggu oleh temannya sendiri yang mengakibatkan siswa tersebut tidak mampu menguasai materi dan pada saat diberi tes kemampuan penalaran matematika siklus I masih banyak siswa yang belum mampu menjawab sesuai dengan langkah-langkah kunci jawaban. Hal ini dikarenakan siswa tidak mengerti maksud dan bahasa soal yang diujikan sehingga siswa cenderung malas dalam menyelesaikan soal. Sehubungan dengan itu peneliti mengadakan revisi terhadap soal-soal yang diujikan dan lebih mudah dipahami oleh siswa maka peneliti melanjutkan ke siklus II atau siklus berikutnya agar kemampuan penalaran matematika siswa meningkat minimal kategori baik yaitu $\geq 80 \%$.

b. Aktivitas Siswa

Dari hasil observasi aktivitas siswa dalam pembelajaran dengan pendekatan terlihat belum dapat mencapai tujuan yang diharapkan. Dari kategori aspek yang dinilai kualifikasi nilai yang diperoleh masih cukup. Hal ini menunjukkan aktivitas siswa masih pasif dalam pembelajaran, untuk itu pada siklus selanjutnya atau pada siklus II akan ditingkatkan. Jika aktivitas meningkat, maka kemampuan penalaran matematika siswa akan meningkat.

c. Sikap Siswa

Ditinjau dari hasil angket siswa yang diperoleh bahwa sikap siswa terhadap pem belajaran dengan pendekatan open ended masih kategori cukup. Hal ini dikarenakan siswa masih merasa ragu, asing dan belum terbiasa melak sanakan pembelajaran tersebut. Dengan demikian untuk meningkatkan aspek penilaian mengenai sikap siswa tersebut maka akan dilanjutkan ke siklus selanjutnya atau siklus II.

\section{Deskripsi Hasil Penelitian Tindakan Kelas (PTK) Siklus II}

Siklus II merupakan tindakan lanjut refleksi pada siklus I. Bertolak dari pelaksanaan siklus I masih ada hal-hal yan belum dicapai, dikarenakan guru dan siswa belum terbiasa menerapkan pembelajaran dengan pendekatan open ended.

a. Tes Kemampuan Penalaran Matematika

Evaluasi tes kemampuan penalaran mate matika siswa pada siklus II dapat diklasifikasi sebagai berikut:

Tabel 6. Pengklasifikasian Kemampuan

Penalaran Matematika Siklus II

\begin{tabular}{c|c|c|c}
\hline No & Nilai & Jumlah & Kualifikasi \\
\hline 1 & $90-100$ & $4(16.7)$ & Sangat Baik \\
\hline 2 & $80-89$ & $8(33.3)$ & Baik \\
\hline 3 & $65-79$ & $8(33.3)$ & Cukup \\
\hline 4 & $55-64$ & $4(16.7)$ & Kurang \\
\hline 5 & $0-54$ & 0 & Sangat Kurang \\
\hline \multicolumn{2}{c}{ Total } & $\mathbf{2 4}$ & \\
\hline
\end{tabular}


Untuk lebih jelasnya dapat dicermati diagram batang di bawah ini yang menggambar kan tingkat kemampuan penalaran matematika siswa pada siklus II sebagai berikut:

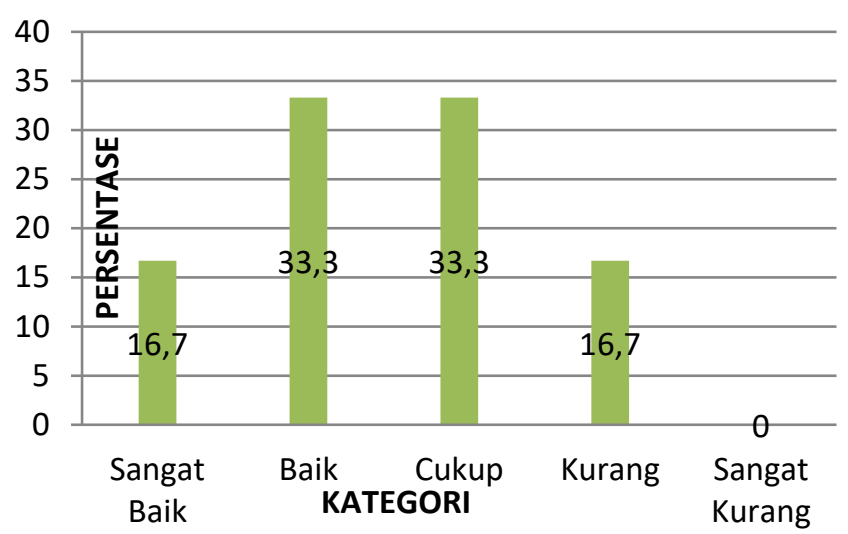

Gambar 3. Diagram Kemampuan Penalaran Matematika Siklus II

Berdasarkan tabel dan diagram diatas, dari 24 siswa yang mengikuti tes diperolah 4 orang atau $16.7 \%$ siswa dengan kategori "Sangat Baik", 8 orang siswa atau $33.3 \%$ pada kategori "Baik", 8 orang siswa atau $33.3 \%$ pada kategori "cukup", 4 orang siswa atau $16.7 \%$ pada kategori "kurang". Karena jumlah siswa yang memperoleh kategori minimal cukup baik sebanyak 20 siswa atau 83.3 $\%$ dari 24 siswa yang mengikuti tes. Berdasarkan hasil tersebut penelitian ini diberhentikan karena sudah memenuhi kriteria yang telah ditentukan.

\section{b. Hasil Observasi Aktivitas Siswa}

Hasil pengamatan terhadap aktivitas siswa dalam pembelajaran setiap pertemuan selama 3 kali tatap muka dinyatakan dengan persentasi. Hasil tersebut disajikan secara ringkas pada tabel berikut:

Tabel 7 Hasil Observasi Aktivitas Siswa

Siklus II

\begin{tabular}{|c|c|c|c|c|c|c|}
\hline \multirow{2}{*}{ No } & \multirow{2}{*}{ Indikator } & \multicolumn{3}{|c|}{ Pertemuan } & \multirow{2}{*}{$\begin{array}{c}\text { Rata- } \\
\text { rata }\end{array}$} & \multirow{2}{*}{$\begin{array}{c}\text { Persen } \\
(\%)\end{array}$} \\
\hline & & $\mathbf{I}$ & II & III & & \\
\hline 1 & $\begin{array}{l}\text { Membaca dan } \\
\text { memahami } \\
\text { soal LKS }\end{array}$ & 3 & 4 & 4 & 3.7 & 91.7 \\
\hline 2 & $\begin{array}{l}\text { Sering } \\
\text { mengajukan } \\
\text { pertanyaan } \\
\text { yang baik }\end{array}$ & 2 & 4 & 4 & 3.3 & 83.3 \\
\hline 3 & $\begin{array}{l}\text { Sering banyak } \\
\text { gagasan dan } \\
\text { usul }\end{array}$ & 3 & 4 & 4 & 3.7 & 91.7 \\
\hline 4 & $\begin{array}{l}\text { Bebas dalam } \\
\text { menyatakan } \\
\text { pendapat }\end{array}$ & 3 & 3 & 3 & 3.0 & 75.0 \\
\hline 5 & $\begin{array}{l}\text { Memiliki } \\
\text { pendapat } \\
\text { sendiri dan }\end{array}$ & 3 & 3 & 3 & 3.0 & 75.0 \\
\hline
\end{tabular}

\begin{tabular}{|c|c|c|c|c|c|c|}
\hline & $\begin{array}{l}\text { mampu } \\
\text { mengutarakan } \\
\text { nya }\end{array}$ & & & & & \\
\hline 6 & $\begin{array}{l}\text { Tidak mudah } \\
\text { terpengaruhi } \\
\text { orang lain }\end{array}$ & 2 & 3 & 3 & 2.7 & 66.7 \\
\hline 7 & $\begin{array}{l}\text { Kerja sama } \\
\text { siswa dalam } \\
\text { kelompok } \\
\end{array}$ & 3 & 4 & 4 & 3.7 & 91.7 \\
\hline 8 & $\begin{array}{l}\text { Perhatian } \\
\text { terhadap } \\
\text { materi } \\
\text { pelajaran }\end{array}$ & 3 & 4 & 4 & 3.7 & 91.7 \\
\hline 9 & $\begin{array}{l}\text { Dapat bekerja } \\
\text { sendiri }\end{array}$ & 4 & 3 & 3 & 3.3 & 83.3 \\
\hline 10 & $\begin{array}{l}\text { Mampu } \\
\text { membuat } \\
\text { kesimpulan }\end{array}$ & 3 & 4 & 4 & 3.7 & 91.7 \\
\hline & Jumlah & $\begin{array}{l}2 \\
9\end{array}$ & 36 & 36 & 33.7 & 841.7 \\
\hline & Rata-rata nilai & \multicolumn{5}{|c|}{3.7} \\
\hline & Persentase & \multicolumn{5}{|c|}{$\mathbf{8 4 . 2 \%}$} \\
\hline & Uualifikasi Nilai & \multicolumn{5}{|c|}{ Sangat Baik } \\
\hline
\end{tabular}

Secara keseluruhan pencapaian aktivitas siswa pada siklus II dapat dilihat pada diagram berikut ini:

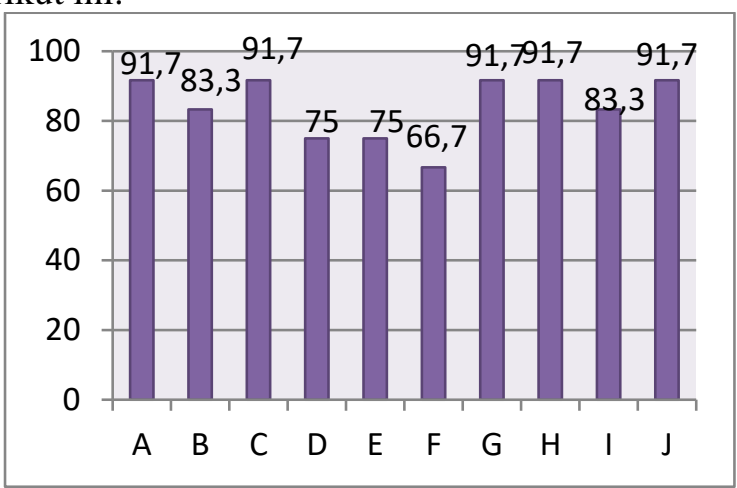

Gambar 4 Kadar Aktivitas Siswa Siklus II

Dari tabel 7 dan gambar 4 hasil observasi aktivitas siswa siklus II di atas dapat dijelaskan persentase klasikal siklus II adalah $84.2 \%$ sedangkan untuk kualifikasi nilai adalah Sangat Baik. Dari hasil observasi aktivitas siswa siklus II di atas dapat dijelaskan bahwa hasil observasi aktivitas siswa telah sesuai dengan apa yang direncanakan dan mengalami peningkatan dari siklus I dan hasilnya telah mencapai indicator yang ditetapkan dalam penelitian ini yaitu $\geq 80 \%$ maka penelitian ini diberhentikan pada siklus II. Dengan demikian maka hasil observasi aktivitas aktif siswa untuk siklus II berjalan dengan baik, dari hasil observasi siklus I ke siklus II mengalami peningkatan. 


\section{c. Sikap Siswa}

Setelah melakukan penyebaran angket sikap siswa maka persentase perolehan pada siklus II ini sebesar $81.7 \%$ dengan kualifikasi nilai Baik. Artinya siswa telah setuju bahwa belajar matematika tersebut itu menyenangkan dan mampu memberikan pengaruh yang sangat baik terhadap peningkatan kemampuan penalaran matematika siswa, dilihat dari hasil respon angket siswa pada siklus II maka pada siklus II ini telah meningkat dan mencapai tujuan yang direncanakan, maka penelitian ini diberhentikan pada siklus II.

\section{Deskripsi Refleksi Pada Siklus II}

Adapun keberhasilan dan kegagalan yang terjadi pada siklus II adalah bahwa persentase yang didapat siklus II ini telah mencapai indikator yang telah ditetapkan hal ini menunjuk kan kemampuan penalaran matematika, aktivitas siswa dan sikap telah sesuai dengan yang direncanakan dalam penelitian ini minimal kategori baik $\geq 80 \%$. Siswa telah terbiasa dengan pembelajaran dengan pendekatan open ended, dan mengalami peningkatan kemampuan penalaran matematika, aktivitas dan sikap siswa dari siklus I ke siklus II, maka tidak perlu lagi perbaikan dan penelitian ini diberhentikan pada siklus II.

\section{Pembahasan} Peningkatan Kemampuan Penalaran
Matematika Siswa

Setelah proses pembelajaran selesai maka siswa diberikan soal tes yang berbentuk essay tiap-tiap siklusnya. Dan hasil tes tersebut meliputi: pada siklus I persentase ketuntasan $66.7 \%$, setelah pembelajaran siklus II maka siswa kembali diberikan tes berbentuk essay sebanyak 5 soal dan memperoleh persentase ketuntasan $83,87 \%$. Adapun peningkatan ke mampuan penalaran matematika siswa dari siklus I ke siklus II adalah sebesar 16.6 sehingga diperoleh peningkatan rata-rata kemampuan penalaran matematika siswa sebesar 0.5 dengan kriteria sedang.

Penelitian ini berakhir setelah selesai pelaksanaan siklus II, karena telah mencapai indikator keberhasilan yang telah ditetapkan, dilihat dari $80 \%$ siswa yang mengikuti tes memperoleh nilai minimal cukup. Sehingga dapat dikatakan bahwa kemampuan penalaran matematika siswa meningkat melalui penerapan Model pembelajaran dengan pendekatan open ended pada di kelas VIII-2 SMP Negeri 7 Padangsidimpuan.

b. Peningkatan Observasi Aktivitas Siswa

Dalam proses belajar mengajar yang menerapkan pembelajaran dengan pendekatan open ended ini aktivitas siswa menjadi bawah perhatian guru. Berdasarkan observasi yang dilakukan pada tiap pertemuannya pada siklus I memperoleh persentase $68.3 \%$ dan pada siklus II hasilnya meningkat menjadi $84.2 \%$. Sehingga dapat bahwa aktivitas siswa meningkat dalam penerapan open ended di kelas VIII-2 SMP Negeri 7 Padangsidimpuan. Adapun peningkat an aktivitas dari siklus I ke siklus II adalah sebesar 12,2 sehingga diperoleh peningkatan rata-rata aktivitas siswa sebesar 0.46 dengan kriteria sedang.

Melihat kekurangan yang masih ada pada aktivitas siswa terhadap pembelajaran pada siklus I belum memenuhi tolak ukur keberhasilan ditentukan maka penelitian dilanjutkan pada siklus II. Hal-hal yang harus diperbaiki pada tindakan siklus II adalah keikutsertaan siswa dalam kelompok

\section{c. Peningkatan Sikap Siswa}

Hasil angket sikap siswa selama diberikan tindakan pada siklus I diperoleh sebesar 57.6 pada kategori kurang baik. Selanjutnya pada siklus II terjadi peningkatan diperoleh sikap siswa sebesar 81.7 dengan kriteria baik. Se hingga dapat dikatakan bahwa sikap siswa meningkat melalui penerapan pembelajaran matematika dengan pendekatan open ended di kelas VIII-2 SMP Negeri 7 Padangsidimpuan. Adapun peningkatan sikap siswa dari siklus I ke siklus II adalah sebesar 24.1 sehingga diperoleh peningkatan rata-rata aktivitas siswa sebesar 0.6 dengan kriteria sedang.

\section{KESIMPULAN}

1. Meningkatnya kemampuan penalaran matematika melalui penerapan pembelajaran matematika dengan pendekatan open ended pada siswa kelas VIII-2. Adapun peningkatan kemampuan penalaran matematika siswa diperoleh sebesar 0.5 dengan kriteria sedang.

2. Meningkatnya aktivitas belajar siswa melalui penerapan pembelajaran matematika dengan pendekatan open ended pada siswa kelas VIII-2. Adapun peningkatan aktivitas siswa diperoleh sebesar 0.46 dengan kriteria sedang.

3. Meningkatnya sikap siswa terhadap mate matika melalui penerapan pembelajaran 
matematika dengan pendekatan open ended pada siswa kelas VIII-2. Adapun peningka tan aktivitas siswa sebesar 0.6 dengan kriteria sedang.

\section{DAFTAR PUSTAKA}

Arikunto, Suharsimi. (2009). Dasar-Dasar Evaluasi Pendidikan, Jakarta: Bumi Aksara.

Arikunto, Suharsimi. (2012). Penelitian Tindakan Kelas. Jakarta: Bumi Aksara.

Depdiknas, (2012). Kurikulum Berbasis Kompetensi Mata Pelajaran Matematika. Pusat Kurikulum - Balitbang : Jakarta.

Keraf, G. (1982). Argumen dan Narasi. Komposisi Lanjutan III, Gramedia: Jakarta

Nohda, N. (2001). A Study Of "Open-Approach" Method in School Mathematics TeachingFocusing On Mathematical Problem
Solving Activities. [on-line]. Available: [31 Maret 2008].

Nurkancana, Wayan. (1986). Evaluasi Pendidikan. Bandung: Remaja Rosda Karya.

Sanjaya, Wina. (2011). Strategi Pembelajaran Berorientasi Standar Proses Pendidikan. Jakarta: Kencana.

Sumarmo, U. (2013). Daya dan Disposisi Matematik: Apa, Mengapa dan Bagaimana Dikembangkan pada Siswa Sekolah Dasar dan Menengah. Seminar Sehari di Jurusan Matematika ITB, Oktober 2013.

Trianto. (2009). Mendesain Model Pembelajaran Inovatif Progresif Konsep, Landasan, dan Implementasinya pada Kurikulum Tingkat Satuan Pendidikan (KTSP), Jakarta: Kencana.

Trianto, (2011). Mendesain Model Pembelajaran Inovatif- Progresif. Jakarta: Kencana. 